\title{
Remedying formal irregularities in wills: a comparative analysis of testamentary rescue in Canada and South Africa
}

\section{Francois du Toit}

To cite this article: Francois du Toit (2020) Remedying formal irregularities in wills: a comparative analysis of testamentary rescue in Canada and South Africa, Oxford University Commonwealth Law Journal, 20:1, 139-162, DOI: 10.1080/14729342.2020.1773017

To link to this article: https://doi.org/10.1080/14729342.2020.1773017

曲 Published online: 04 Jun 2020.

Submit your article to this journal $\widetilde{ }$

III Article views: 112

Q View related articles ¿

View Crossmark data \lceil 


\title{
Remedying formal irregularities in wills: a comparative analysis of testamentary rescue in Canada and South Africa
}

\author{
Francois du Toit
}

Department of Private Law, University of the Western Cape, Bellville, South Africa

\begin{abstract}
This article examines the testamentary rescue provisions contained in the statutes governing wills in Manitoba, British Columbia and South Africa, as well as some of the jurisprudence on the interpretation and application of these provisions. The article thus provides an instructive legal comparative analysis of how formally irregular wills are judicially rescued and, therefore, how testamentary formalism is tempered to ensure that testamentary intentions embodied in informal documents are effectuated in the three jurisdictions under discussion. The article also evaluates (in broad terms) the efficacy of Manitoba's, British Columbia's and South Africa's respective testamentary rescue dispensations, and attends to some lessons and possible solutions to challenges arising from these jurisdictions' engagement with testamentary rescue.
\end{abstract}

ARTICLE HISTORY Received 11 August 2019; Accepted 15 December 2019

KEYWORDS Execution formalities; formally irregular wills; curative power; dispensing power; condonation power; testamentary intentions

\section{Introduction}

The statutes governing wills in many Commonwealth member states are historically rooted in two English sources, namely the Statute of Frauds 1677 (29 Car 2 c 3) and the Wills Act 1837 (7 Will 4 \& 1 Vict c 26). This is especially true of, amongst others, Australia, ${ }^{1}$ Canada (with the exception of Québec) ${ }^{2}$ and New Zealand, ${ }^{3}$ each of which derive their laws pertaining to wills directly from English law. The will forms prescribed by the wills statutes in the aforementioned jurisdictions thus correspond greatly to the will form laid down in the 1837 Act, which also impacted formal aspects of testamentary succession

\section{CONTACT Francois du Toit @ fdutoit@uwc.ac.za}

${ }^{1}$ Nicola Peart, 'Testamentary Formalities in Australia and New Zealand' in Kenneth GC Reid, Marius J de Waal and Reinhard Zimmermann (eds), Comparative Succession Law: Testamentary Formalities (Oxford University Press 2011) 333.

${ }^{2}$ Thomas G Feeney, The Canadian Law of Wills: Probate (3rd edn, Butterworths 1987) 82.

${ }^{3}$ Peart (n 1) 333-34.

๑) 2020 Faculty of Law, Oxford University 
in some Commonwealth member states (or territories within such member states) where the laws of wills are founded on civil law tenets. For example, South Africa (with Roman-Dutch law as its civilian common law ${ }^{4}$ ) currently recognises only one will form, namely the statutory (underhand) will that is based on the will form prescribed by the 1837 Act. $^{5}$ Similarly, the Civil Code of Québec (inspired by the French civil law contained in the Napoleonic Code ${ }^{6}$ ) acknowledges a number of will forms, one of which is aptly described as the 'will following the form derived from the laws of England'. ${ }^{7}$ All the aforementioned will forms thus draw on the formality prescripts of the 1837 Act.

The jurisdictions mentioned above generally require a combination of writing, signature, the presence of witnesses and attestation for the validity of wills (or, in the case of Québec, for the execution of the specific will form derived from English law known as 'the will made in the presence of witnesses ${ }^{\prime 8}$ ). Moreover, these jurisdictions have historically demanded strict compliance with testamentary formalities to ensure that wills are validly executed. Any deviation from these formalities, no matter how obscure or ostensibly innocuous, voids the affected will absolutely and irreparably. ${ }^{9}$ Testamentary formalities perform four core functions that explain this historical insistence on wills' formal regularity. Legal scholars (particularly American scholars) have canvassed these functions on numerous occasions and their endeavours need not be repeated here. ${ }^{10}$ For the purposes of this article, the following brief description and explanation of the four functions will suffice:

- the evidentiary function: a formally regular will provides evidence of the testator's volition regarding the distribution of his or her property after death;

- the protective function: a will's formal regularity ensures that its contents and execution are the products of the testator's free and unfettered choice;

${ }^{4}$ Eduard Fagan, 'Roman-Dutch Law in its South African Historical Context' in Reinhard Zimmermann and Daniel Visser (eds), Southern Cross: Civil Law and Common Law in South Africa (Clarendon Press 1996) 3364.

${ }^{5}$ Marius J de Waal, 'Testamentary Formalities in South Africa' in Reid, de Waal and Zimmermann (n 1), 38485.

${ }^{6} E$ Fabre-Surveyer, 'The Civil Law in Québec and Louisiana' (1939) 1 Louisiana Law Review 649, 657.

${ }^{7}$ Tim Hewson, 'Why We Don't Support Québec Wills' (The Canadian Legal Wills Blog, 29 September 2014) $<$ www.legalwills.ca/blog/quebec-wills/> accessed 7 August 2019.

${ }^{8}$ Civil Code of Québec SQ 1991 c 64, art 727.

${ }^{9}$ The South African wills statute (Wills Act 7 of 1953 (WA 1953)) provides a case in point. WA 1953, s 2(1)(a) stipulates that 'no will executed on or after the first day of January, 1954 [the Act's commencement date], shall be valid unless ...', and thereafter follows the formalities for the execution of a valid will. The statutory directive is thus clear: compliance with the prescribed formalities is an absolute requirement for the formal validity of South African wills.

${ }^{10}$ See, eg, John H Langbein, 'Substantial Compliance with the Wills Act' (1975) 88(3) Harvard Law Review 489, 492-98; Leigh A Shipp, 'Equitable Remedies for Nonconforming Wills: New Choices for Probate Courts in the United States' (2005) 79 Tulane Law Review 723, 725; George Holmes, 'Testamentary Formalism in Louisiana: Curing Notarial Will Defects Through a Likelihood-of-Fraud Analysis' (2014) 75 Louisiana Law Review 511, 516-17. 
- the cautionary function: compliance with testamentary formalities establishes that the testator comprehends the significance of the act of willmaking; and

- the channelling function: standardised will forms occasion the contents of most wills to correspond, thereby increasing administrative efficacy and certainty for testators when they draft their wills.

Steadfast adherence to testamentary formalism - notwithstanding the aforementioned functional importance of strict compliance with testamentary formalities - is nevertheless problematic when a document contains a person's intentions regarding the devolution of his or her property after death, but the document is formally irregular and is thus not a valid will capable of effectuating that person's post mortem dispositive plan. This problem arises because statutory insistence on strict compliance with testamentary formalities can be at odds with one of the cornerstones of the law of wills, namely protecting and giving effect to a testator's intentions. ${ }^{11}$ Insisting on strict compliance at the expense of effectuating a testator's dispositive plan therefore amounts to an apparent prioritisation of form over substance in the law of succession. ${ }^{12}$ It is consequently unsurprising that many legal systems, including those of some Commonwealth member states, have developed and implemented mechanisms to combat the adverse effects that testamentary formalism can have on testamentary intent. One such mechanism is the statutory conferral of a power that permits a court to condone, cure and/ or dispense with formal irregularities in wills, thereby ensuring that technical defects in the execution of wills do not frustrate testators' intentions regarding the devolution of their property after death. This article employs the term 'testamentary rescue' to describe this practice.

Australia, Canada and South Africa are three Commonwealth member states wherein wills statutes (including, where applicable, wills statutes of states and territories within those member states) bestow such powers on courts to rescue formally irregular wills. However, the statutory provisions that confer these powers, although sharing the objective of safeguarding testators' intentions despite non-compliance with testamentary formalities, are invariably formulated differently; lay down dissimilar requirements for the exercise of said powers; and are interpreted and applied by the courts in a manner which yields fluctuating and at times troubling outcomes. A comparative analysis of these provisions and the judicial exercise of the powers they confer therefore yields valuable insights into different jurisdictions' engagement with the challenges posed by testamentary formalism. Additionally, and arguably more importantly, such a comparative analysis provides

\footnotetext{
${ }^{11}$ Holmes (n 10) 518.

${ }^{12}$ Mark Glover, 'Decoupling the Law of Will-Execution' (2014) 88 St John's Law Review 597, 604.
} 
instructive direction to jurisdictions looking to incorporate similar provisions in their wills statutes.

This article undertakes a comparative analysis of testamentary rescue in Canada and South Africa. ${ }^{13}$ It does so by considering the rescue provisions in the wills statutes of two Canadian jurisdictions - namely, Manitoba and British Columbia ${ }^{14}$ - and South Africa. The article focusses, insofar as its engagement with Canadian law is concerned, only on Manitoba and British Columbia not merely for reasons of brevity and efficacy, but also because the current Manitoban rescue provision has been in operation for about as long as its South African counterpart, whereas the British Columbian rescue provision is a more recent addition to that jurisdiction's law of wills. These timelines permit an instructive comparison of the evolving judicial interpretations and applications of rescue provisions over relatively long periods (in the cases of Manitoba and South Africa), in addition to the courts' engagement with a comparatively novel rescue provision (in the case of British Columbia).

\section{Testamentary formalities and the rescue provisions of wills statutes in Manitoba, British Columbia and South Africa}

Testamentary formalities for the formal (non-holograph) will in Manitoba and British Columbia as well as the statutory will in South Africa, in accordance with these jurisdictions' adherence to the will form laid down in the 1837 Act, focus on: the signing of a will by the testator or someone on the testator's behalf; ${ }^{15}$ the making or acknowledging of this signature in the presence of two or more witnesses who are simultaneously present; ${ }^{16}$ and the subsequent attestation and signing of the will by these witnesses. ${ }^{17}$ All three wills statutes direct that a will is formally valid only upon compliance with all the aforementioned formalities. ${ }^{18}$ In addition, the Manitoban and British Columbian statutes expressly require that a will must be in writing. ${ }^{19}$ The South African statute contains no comparable express directive, but a writing requirement is nevertheless inferred on the basis that compliance with the statute's prescribed formalities is possible only in respect of written documents. ${ }^{20}$

\footnotetext{
${ }^{13}$ See François du Toit, 'Testamentary Rescue: An Analysis of the Intention Requirement in Australia and South Africa' (2014) 23 Australian Property Law Journal 56 for a legal comparative consideration of Australian courts' 'dispensing power' and South African courts' 'condonation power' regarding formal irregularities in wills.

${ }^{14}$ Other Canadian jurisdictions that have incorporated rescue provisions in their wills statutes include Alberta, New Brunswick, Prince Edward Island, Québec and Saskatchewan.

${ }^{15}$ The Wills Act CCSM (RSM 1988) c W150 (Manitoba) (TWA 1988), s 4(a) and 7(1); Wills, Estates and Succession Act SBC 2009 c 13 (British Columbia) (WESA 2009), s 37(1)(b); WA 1953, s 2(1)(a)(i).

${ }^{16}$ TWA 1988, s 4(b); WESA 2009, s 37(1)(b); WA 1953, s 2(1)(a)(ii).

${ }^{17}$ TWA 1988, s 4(c); WESA 2009, s 37(1)(c); WA 1953, s 2(1)(a)(iii).

${ }^{18}$ TWA 1988, s 4; WESA 2009, s 37(1); WA 1953, s 2(1)(a).

${ }^{19}$ TWA 1988, s 3; WESA 2009, s 37(1)(a).

${ }^{20} \mathrm{MJ}$ de Waal and MC Schoeman-Malan, Law of Succession (5th edn, Juta 2015) 55-56.
} 
Section 23 of the Manitoban statute grants the 'dispensation power', pursuant to the terms of which a court can undertake testamentary rescue. It has been operational in its current form since $1995^{21}$ and provides:

Dispensation power

Where, upon application, if the court is satisfied that a document or any writing on a document embodies

(a) the testamentary intentions of a deceased; or

(b) the intention of a deceased to revoke, alter or revive a will of the deceased or the testamentary intentions of the deceased embodied in a document other than a will;

the court may, notwithstanding that the document or writing was not executed in compliance with any or all of the formal requirements imposed by this Act, order that the document or writing, as the case may be, be fully effective as though it had been executed in compliance with all the formal requirements imposed by this Act as the will of the deceased or as the revocation, alteration or revival of the will of the deceased or of the testamentary intention embodied in that other document, as the case may be.

Section 58 of the British Columbian statute bestows a 'curative power' through which a court can, on application, undertake testamentary rescue. This provision has been in operation since $2014^{22}$ and provides:

Court order curing deficiencies

(1) In this section, 'record' includes data that
(a) is recorded or stored electronically,
(b) can be read by a person, and
(c) is capable of reproduction in visible form.

(2) On application, the court may make an order under subsection (3) if the court determines that a record, document or writing or marking on a will or document represents

(a) the testamentary intentions of a deceased person,

(b) the intention of a deceased person to revoke, alter or revive a will or testamentary disposition of the deceased person, or

(c) the intention of a deceased person to revoke, alter or revive a testamentary disposition contained in a document other than a will.

(3) Even though the making, revocation, alteration or revival of a will does not comply with this Act, the court may, as the circumstances require, order

\footnotetext{
${ }^{21}$ The original form of section 23 of TWA 1988 was amended by section 2 of The Wills Amendments Act SM 1995 c 12, which came into force on 3 November 1995.

${ }^{22}$ WESA 2009 was assented to on 29 October 2009 but did not come into force until 31 March 2014.
} 
that a record, or document, or writing or marking on a will or document be fully effective as though it had been made

(a) as the will or part of the will of the deceased person,

(b) as a revocation, alteration or revival of the will of the deceased person, or

(c) as the testamentary intention of the deceased person.

(4) If an alteration to a will makes a word or provision illegible and the court is satisfied that the alteration was not made in accordance with this Act, the court may reinstate the original word or provision if there is evidence to establish what the original word or provision was.

Section 2(3) of the South African statute affords the 'condonation power' through which a court can undertake testamentary rescue. This provision came into force in $1992^{23}$ and provides:

Formalities required in the execution of a will

(3) If a court is satisfied that a document or the amendment of a document drafted or executed by a person who has died since the drafting or execution thereof, was intended to be his will or an amendment of his will, the court shall order the Master to accept that document, or that document as amended, for the purposes of the Administration of Estates Act, 1965 (Act 66 of 1965), as a will, although it does not comply with all the formalities for the execution or amendment of wills referred to in subsection (1). ${ }^{24}$

Before attending to a number of substantive matters regarding testamentary rescue pursuant to the abovementioned provisions, the following four preliminary points deserve mention:

- the three jurisdictions employ different terminology when referencing the power to rescue formally irregular wills - the Manitoban statute utilises 'dispensation power' and Manitoba courts generally abide by this term ${ }^{25}$ or its derivative 'dispensing power'; ${ }^{26}$ courts in British Columbia prefer 'curative power'; ${ }^{27}$ whereas South African courts favour 'power to condone'; ${ }^{28}$

- the rescue provisions' ambits, as stated in the respective statutes, vary - in Manitoba and British Columbia, the power of testamentary rescue

\footnotetext{
${ }^{23}$ The original form of WA 1953 commenced on 1 January 1954 but section 2(3) did not form part of the statute until the Law of Succession Amendment Act 43 of 1992 entered into force on 1 October 1992.

${ }^{24}$ WA 1953, s 2(1)(a) contains the execution formalities and s 2(1)(b) contains the amendment formalities in respect of South African wills.

${ }^{25}$ See, eg, George v Daily (1997) 115 Man R (2d) 27 (Manitoba Court of Appeal) [2].

${ }^{26}$ See, eg, Weselowski v Weselowski 2003 MBQB 191 (Court of Queen's Bench of Manitoba) [16].

${ }^{27}$ See, eg, Estate Beck (Re) 2015 BCSC 676 (Supreme Court of British Columbia) [16].

${ }^{28}$ See, eg, Giles v Henriques 2008 (4) SA 558 (C) (Cape of Good Hope Provincial Division High Court (now forming part of the Western Cape Division of the High Court of South Africa (HCSA-WC))) [39].
} 
encompasses the execution, alteration, revocation and revival of wills, whereas South Africa permits the judicial condonation of irregularities in the execution and amendment of wills only; ${ }^{29}$

- the three rescue provisions share the objective of having a rescued document regulate the devolution of the deceased's property after death by assimilating that document into the legal processes that govern such devolution - in Manitoba and British Columbia, a rescued document will be admitted to probate, ${ }^{30}$ and section 2(3) of the South African statute instructs the Master of the High Court to accept the rescued document for purposes of the administration of the deceased's estate (which is South African law's functional equivalent of admitting a will to probate); and

- the rescue provisions' recourse to discretion (or lack thereof) - Manitoba's and British Columbia's rescue provisions are cast in permissive terms insofar as the use of the word 'may' in these provisions imbues courts in these jurisdictions with a discretion regarding whether or not to grant an application for testamentary rescue; ${ }^{31}$ the South African provision, on the other hand, is formulated peremptorily insofar as the use of the word 'shall' in this provision compels a court, upon the requirements for testamentary rescue having been met, to issue a condonation order to the Master. $^{32}$

\section{The requirements for testamentary rescue in Manitoba, British Columbia and South Africa}

Section 23 of the Manitoban statute states, at least on the face of it, only a single requirement to be satisfied in order for a court to exercise the

\footnotetext{
${ }^{29} \mathrm{~A}$ formally irregular document that contains a revocatory clause will, if it is condoned in terms of the WA 1953's rescue provision, of course revoke the deceased's existing will(s): De Waal and Schoeman-Malan (n 20) 91. WA 1953, s 2 A moreover empowers a court to condone informal acts of revocation that do not occasion revocation in terms of the common law. WA 1953 therefore contains mechanisms that facilitate testamentary rescue regarding the revocation of wills and is thus aligned, at least to an extent, with its counterparts from Manitoba and British Columbia in this regard. It appears unlikely that a South African court will condone a formally irregular document that purports to revive a revoked will because such a reviving document is not intended as a will or an amendment of a will as contemplated in WA 1953, s 2 (3). In light of the fact that the operational ambits of the three statutes' rescue provisions are varied, this article focusses principally on the rescue of documents that are invalid for want of compliance with testamentary execution formalities.

${ }^{30}$ See, eg, Timm v Rudolph 2016 MBQB 123 [1] (regarding TWA 1988, s 23) and Estate Mace (Re) 2018 BCSC 1284 [35] (regarding WESA 2009, s 58).

${ }^{31}$ See, eg, Weselowski (n 26) [27] (where Schulman J remarked that TWA 1988, s 23 'vests a discretion in [the MBQB] as to whether and in what circumstances to grant the application') and Estate of Young 2015 BCSC 182, [17] (where Dickson J acknowledged that WESA 2009, s 58 'confers a discretion on the [BCSC] to relieve against the consequences of non-compliance with testamentary formalities ... ').

${ }^{32}$ See, eg, Harlow v Becker 1998 (4) SA 639 (D) (Durban and Coast Local Division High Court (now forming part of the KwaZulu-Natal Division of the High Court of South Africa (HCSA-KZN))) 642I (where Thirion J stated that, once a court is satisfied that the requirements of WA 1953, s 2(3) have been met, 'the Court [has] no discretion in the matter but [is] obliged to order the Master to accept the document as a will ...').
} 
dispensation power, namely that the document in question must embody the deceased's testamentary intentions - the 'testamentary intentions requirement'. This is indeed how the Manitoba Court of Appeal ostensibly interpreted section 23 in George $v$ Daily ${ }^{33}$ - the leading Manitoban case on point wherein Philp JA (Scott CJM concurring) opined that section 23 demands of a court to establish on a balance of probabilities that the document at issue contains the deceased's testamentary intentions. ${ }^{34}$ 'Testamentary intentions' in this context mean, according to Philp JA, that the deceased must have evinced his or her animus testandi as a 'deliberate or fixed and final expression of intention as to the disposal of his/her property on death. ${ }^{35}$ Dewar J interpreted this statement in Timm $v$ Rudolph ${ }^{36}$ to mean that the deceased must have contemplated the document at issue as a testamentary document to be admitted to probate when the time came, and that the deceased must thus not have regarded it simply as a document that disclosed his or her distributive wishes at the time. ${ }^{37}$ Dewar J opined further that, if the court is satisfied that the document indeed embodies the deceased's testamentary intentions and the application that it be given full legal effect is unopposed, no practical hindrance precludes a judge from exercising the dispensation power in terms of section $23 .^{38}$

Section 23's testamentary intentions requirement can thus be designated as its core requirement. It is, however, important to note that, in Weselowski v Weselowski, ${ }^{39}$ the Manitoba Court of Queen's Bench dismissed an application brought under section 23 because Schulman J reasoned (amongst other things) that the document brought before the court in that case was not 'a credible document'. ${ }^{40}$ This reasoning suggests that the judicial exercise of the dispensation power is also dependent on a court being satisfied regarding the authenticity of the document at issue - the 'authenticity requirement'. In fact, in light of the reasoning in Weselowski, it is arguable that the authenticity requirement is the threshold requirement that must be satisfied even before a court proceeds to an inquiry regarding whether or not the testamentary intentions requirement has been met.

The British Columbian statute corresponds with its Manitoban counterpart insofar as the core requirement for the judicial exercise of the curative power granted by section 58 is concerned. Dickson J therefore reasoned in Estate of Young ${ }^{41}$ that ' $[\mathrm{t}]$ he court must be satisfied that a document represents the

\footnotetext{
${ }^{33}$ George (n 25).

${ }^{34}$ ibid [20], [61]. See also McNeil v Snidor Estate 2008 MBQB 187, [19].

${ }^{35}$ George (n 25) [65]-[66] (citations omitted).

${ }^{36} \mathrm{Timm}$ (n 30).

${ }^{37}$ ibid [29].

${ }^{38}$ ibid [1].

${ }^{39}$ Weselowski (n 26).

${ }^{40}$ ibid [27].

${ }^{41}$ Young (n 31).
} 
testamentary intentions of the deceased before granting an order that it is fully effective as a will pursuant to s 58(3) ...'.42 Dickson J moreover emphasised that section 58, and thus (correspondingly) section 23 of the Manitoban statute, does not specify any execution requirements or any other formal requirements in order for a court to bestow full legal effectiveness on such a testamentary document. ${ }^{43}$

Dickson J's analysis of the jurisprudence in relation to section 23 of the Manitoban statute, undertaken to inform her Ladyship's interpretation and application of section 58 of the British Columbian statute, yielded an outcome that confirms the abovementioned dual-requirement approach in respect of the Manitoban provision - a dual-requirement equally applicable under British Columbian law. In this connection, Dickson J reasoned:

[A] determination of whether to exercise the court's curative power with respect to a non-compliant document is inevitably and intensely fact-sensitive. Two principal issues for consideration emerge from the post-1995 Manitoba authorities. The first is an obvious threshold-issue: is the document authentic? The second, and core, issue is whether the non-compliant document represents the deceased's testamentary intentions. ${ }^{44}$

Conversely, the requirements for testamentary rescue in accordance with the terms of section 2(3) of the South African statute are more extensive when compared to those of its two Canadian counterparts. Specifically, the Supreme Court of Appeal of South Africa ruled in Van Wetten $v$ Bosch $^{45}$ that exercise of the condonation power is subject to the court being satisfied that the deceased drafted or executed the document at issue, in addition to being satisfied that the deceased intended that document as his or her will. $^{46}$ Furthermore, in Van der Merwe v Master of the High Court, ${ }^{47}$ the very same Court appeared to have regard to an additional requirement by referring to the 'aura of authenticity' of a document that was the subject of a condonation application. ${ }^{48}$ It is therefore arguable that section $2(3)$ sets the same threshold requirement, namely the authenticity requirement, as well as the same core requirement, namely the testamentary intentions requirement, as its two Canadian counterparts. Moreover, the content of section 2(3)'s testamentary intentions requirement is substantially the same as that of the equivalent Manitoban and British Columbian statutory provisions, given that, in Van Wetten, the Court said that this requirement does not pertain to what the document in question means, but rather to whether or not the

\footnotetext{
${ }^{42}$ ibid [19].

${ }^{43}$ ibid [21].

${ }^{44}$ ibid [34]. The Court of Appeal for British Columbia has since cited Dickson J's analysis with apparent approval: see Hadley Estate (Re) [2017] BCCA 311 [36].

${ }^{45}$ [2003] ZASCA 85 (Supreme Court of Appeal of South Africa).

${ }^{46}$ ibid [14].

${ }^{47}$ [2010] ZASCA 99.

${ }^{48}$ ibid [17].
} 
deceased intended it as his or her will. ${ }^{49}$ Section 2(3), however, interposes an additional requirement between the authenticity requirement and the testamentary intentions requirement, namely, as noted above, that the deceased must have drafted or executed the document at issue. Neither section 23 of the Manitoban statute nor section 58 of the British Columbian statute contains a corresponding prescript. In Bekker $v$ Naude, ${ }^{50}$ the same Court observed that this 'drafted-or-executed requirement' serves to bolster compliance with the authenticity requirement insofar as establishing that the deceased indeed drafted or executed the document in question provides some guarantee regarding that document's credibility. ${ }^{51}$

Having said that, it must be noted that the drafted-or-executed requirement prescribed by section 2(3) of the South African statute states the two apposite actions in the alternative: the deceased must either have drafted or have executed the document in question. 'Executed' in this regard ostensibly means that the deceased must either have commenced with executing the document but never have completed the execution process, or have appended his or her signature at least once to the document. ${ }^{52}$ If a document was not executed in the aforementioned manner, it can be condoned only if the deceased indeed drafted it. In Bekker, the court ruled that the legislature contemplated personal drafting in this regard - in other words, the deceased must have created the document himself or herself by, for example: penning it in his or her handwriting; typing or computer-generating it himself or herself; or him or her dictating it with the dictation being taken down verbatim by a scribe. ${ }^{53}$

\section{The application of the rescue provisions in Manitoba, British Columbia and South Africa: correlations and contrasts}

This section of the article analyses the application of the rescue provisions in the three jurisdictions under discussion with reference to specific document types that have been considered by the courts in rescue cases in these jurisdictions. This section therefore highlights various correlations and contrasts in judicial engagement with testamentary rescue in the three jurisdictions.

\section{Draft wills}

The rescue provisions in all three jurisdictions generally preclude the rescue of draft wills, whether such drafts were prepared by the prospective testator or

\footnotetext{
${ }^{49}$ Van Wetten (n 45) [16]. See also De Reszke v Czeslaw Maras [2005] ZASCA 137, [11]-[12].

${ }^{50}[2003]$ ZASCA 40.

${ }^{51}$ ibid [16].

${ }^{52}$ De Waal and Schoeman-Malan (n 20) 73. See also MC Wood-Bodley, 'Did You Say "Asinine" Milord? Bekker v Naude 20035 SA 173 (SCA)' (2004) 25 Obiter 222, 228-29.

${ }^{53}$ Bekker (n 50) [8], [20]. See also Grobler v Master of the High Court [2019] ZASCA 119, [14].
} 
by someone else on the prospective testator's behalf. Courts in all three jurisdictions have refused to give such drafts legal effect because these documents do not necessarily contain prospective testators' complete and final testamentary intentions. This strong stance against the rescue of draft wills in all three jurisdictions is unsurprising in light of the fact that the testamentary intentions requirement is the core requirement for testamentary rescue in these jurisdictions. In Timm, the Manitoba Court of Queen's Bench therefore dismissed a section 23 application to rescue a draft will prepared by an articling student on the deceased's instructions. The deceased passed away without having seen, read, approved or signed the draft. ${ }^{54}$ Dewar J noted that the draft contained clauses (albeit standard clauses that commonly appear in wills) that were not discussed with the deceased at the time she gave instructions for the drafting of her will. ${ }^{55}$ Dewar J reasoned that even a draft will that contains standard clauses must be presented to a testator for his or her consideration at the time of execution in order to ensure that the document indeed embodies the testator's intentions. Dewar J therefore regarded it as 'presumptuous for a legal regime to encourage the probate of a will when the details of some gifts have never been discussed with the client'. ${ }^{56}$

In Bailey Estate $(R e){ }_{1}^{57}$ the Supreme Court of British Columbia likewise refused a section 58 application to rescue a draft will prepared for the deceased by her lawyer. The lawyer emailed the draft to her client (the deceased), who acknowledged receipt thereof and indicated that she would review it. ${ }^{58}$ The deceased however passed away approximately ten months later without the draft having been executed. ${ }^{59}$ Hyslop J reasoned that the deceased did not regard the draft's preparation and anticipated execution as a priority because (amongst other things): she gave various instructions regarding the draft at different times; she missed meetings with her lawyer regarding the draft; she did not read previous drafts of the will; and she provided no indication to her lawyer as to whether or not she was satisfied with the draft. ${ }^{60}$ Under these circumstances, according to Hyslop J, '[t]here simply was no expression by [the deceased] whether the ... draft will was a final expression of her testamentary intentions. ${ }^{61}$ Hyslop $\mathrm{J}$ consequently refused to give legal effect to the draft will because, in her Ladyship's estimation, the deceased never adopted the draft, in particular

\footnotetext{
${ }^{54} \mathrm{Timm}$ (n 30) [16]-[19].

${ }^{55}$ ibid [38].

${ }^{56}$ ibid. See also Sawatzky v Sawatzky Estate 2009 MBQB 222.

${ }^{57} 2016$ BCSC 1226.

${ }^{58}$ ibid [23].

${ }^{59}$ ibid [27].

${ }^{60}$ ibid [50].

${ }^{61}$ ibid [53].
} 
insofar as '[s] he never told anyone that she was satisfied with it and wanted to sign $\mathrm{it}^{\prime}{ }^{62}$

The former Supreme Court of South Africa delivered a corresponding decision in Ramlal $v$ Ramdhani's Estate ${ }^{63}$ when it dismissed a section 2(3) application for the condonation of a draft will. The deceased's attorney prepared the draft in accordance with the deceased's directives, but the deceased passed away without having seen or signed the draft will. ${ }^{64}$ Richings AJ reasoned as follows:

I fail to see how, when a document as is referred to in the subsection has been drafted, not by the would-be testator himself but on his instruction and he dies before reading it and approving its contents, it can be said that he 'intended' that that particular document was to be his last will. Testators are notoriously fickle, there always exists the possibility of their wishes changing in the interval between the giving of instructions and the final approval of what has been drafted. Every attorney knows that even where ordinary commercial agreements are concerned, it is not unknown for alterations to be suggested and effected while the document embodying the terms of the agreement is being read through for the purposes of signature. How much more so, when the document in question is intended to embody the client's last wishes upon this earth. ${ }^{65}$

It must be noted that, at the time of the Ramlal decision, South African trial judges were still divided on the issue of whether an unexecuted document prepared for a deceased by another was capable of condonation. The Supreme Court of Appeal of South Africa subsequently settled this issue in Bekker when it held that a document prepared by someone else is condonable only if the deceased in fact executed it (as demanded by section 2(3)). ${ }^{66}$ In Bekker's aftermath, a case concerning a document similar to the one at issue in Ramlal will therefore not turn on the testamentary intentions requirement, but rather on the drafted-or-executed requirement.

\section{Instructions and application forms}

Logic dictates that, if courts are loath to rescue draft wills in the three jurisdictions under discussion, it can be assumed that these courts will regard the rescue of instructions for the drafting of wills, as well as completed application forms for the same purpose, with even greater reluctance. This assumption rests on the rational deduction that, if draft wills prepared on prospective testators' instructions do not meet the testamentary intentions requirement

\footnotetext{
${ }^{62}$ ibid [62]. See also Herod Estate (Re) 2017 BCSC 318.

${ }^{63} 2002$ (2) SA 643 (N) (Natal Provincial Division of the Supreme Court of South Africa (SCSA-N) (now forming part of HCSA-KZN)).

${ }^{64}$ ibid $645 \mathrm{C}-\mathrm{H}$.

${ }^{65}$ ibid 647D-G (errors and emphasis in original). See also Henwick v The Master 1997 (2) SA 326 (C) (Cape of Good Hope Provincial Division of the Supreme Court of South Africa (SCSA-C) (now forming part of H(SA-WC)).

${ }^{66}$ De Waal and Schoeman-Malan (n 20) 73. See also Wood-Bodley (n 52) 228-29.
} 
prescribed by the rescue provisions in these jurisdictions, then written instructions and completed application forms, as documents that precede will drafting, cannot possibly meet this requirement. This is indeed the general tenor of case law on point in the three jurisdictions, but some decisions deviate curiously from this norm.

For the sake of brevity, engagement with Canadian authority can be limited to the seminal judgment in George, ${ }^{67}$ where the Manitoba Court of Appeal allowed an appeal against an order of the Manitoba Court of Queen's Bench to give legal effect to written instructions for the drafting of a new will given by the deceased to his accountant. Philp JA (Scott CJM concurring) reasoned that no evidence was adduced to prove that the deceased intended the letter containing the instructions to have dispositive effect or to operate provisionally as a testamentary instrument until the drafting of the prospective will occurred. ${ }^{68}$ The instructions letter was, in Philp JA's estimation, 'never touched by the animus testandi of the deceased' ${ }^{\prime 69}$ and was thus not susceptible to testamentary rescue. ${ }^{70}$

The same conclusion was reached in the South African decision of Ex Parte Maurice $^{71}$ when the court was asked to rescue a joint will that the deceased had drafted and then sent to a colleague to 'knock it into shape' and thereafter to request an attorney to see to 'finalising it in legal jargon'. ${ }^{72}$ The deceased passed away before this could be done. Selikowitz J dismissed the section 2(3) application, concluding that the deceased did not intend the handwritten document to be a will, but instead regarded it as mere instructions for the drafting of a will that he had to approve finally. ${ }^{73}$ Selikowitz J, in reaching this conclusion, reasoned that, had the South African legislature intended to empower a court to rescue a document that simply expresses a testator's wishes for the distribution of his or her estate, section 2(3) would have focussed pertinently on the deceased's distribution intentions rather than his or her testamentary intentions. ${ }^{74}$ The fact that the legislature did not do so thus underscores, in Selikowitz J's opinion, the necessity of compliance with the testamentary intentions requirement, thereby rendering instructions for the drafting of a will (being merely dispositive rather than testamentary in nature) beyond the rescue provision's ambit. $^{75}$

\footnotetext{
${ }^{67}$ George (n 25).

${ }^{68}$ ibid [78].

${ }^{69}$ ibid [82].

${ }^{70}$ ibid [82]-[85].

${ }^{71} 1995$ (2) SA 713 (C) (SCSA-C (now forming part of HCSA-WC)).

${ }^{72}$ ibid 717D.

${ }^{73}$ ibid 717E-F.

${ }^{74}$ ibid 716I-717A.

${ }^{75}$ ibid $717 A-B$.
} 
Mabika v Mabika ${ }^{76}$ - a curious South African decision on the rescue of will drafting instructions - is patently at odds with the logical outcomes achieved in George and Maurice. In Mabika, the deceased had completed a document on her bank's letterhead entitled 'Application For the Drafting of a Will' that mandated the bank to prepare a will in accordance with her instructions. ${ }^{77}$ More specifically, the deceased wrote her full name and identification number on the form; signed the form's terms and conditions; and made a handwritten statement on the form regarding burial arrangements and the division of property and investments amongst her children. ${ }^{78}$ It is not apparent from the judgment whether the bank indeed prepared the deceased's will but, if it did, the deceased died without having executed it. The applicants - namely, the deceased's children and grandchild - presented the completed application form to the court for condonation pursuant to section 2(3) of the Wills Act. ${ }^{79}$ Moshidi J granted the condonation order. $^{80}$

It is important to note that, had the condonation order not been granted, the deceased would have died intestate and her husband (with whom she was estranged as a result of his cruelty towards her ${ }^{81}$ ) would have been one of her intestate heirs. ${ }^{82}$ In this connection, Moshidi J engaged only superficially with section 2(3)'s requirements and instead focussed primarily on the fact that the deceased evidently did not want her husband to benefit upon her death and that, under the circumstances, it would be 'greatly unjust' not to accept the application form as the deceased's last will. ${ }^{83}$ In light of the foregoing, Moshidi J concluded, despite his Honour describing the application form as merely an instruction to draft her will, ${ }^{84}$ that the deceased 'clearly intended the document to be her final will but did not survive to sign $i^{\prime}{ }^{\prime 85}$ This statement is, with respect, regrettably dubious. If 'the document' that Moshidi $J$ had in mind was the will that the bank would ultimately draft pursuant to the application form, section 2(3)'s testamentary intentions requirement does not justify granting a condonation order in respect of the application form. If, on the other hand, 'the document' was the application form itself, it is difficult to conceive, in light of decisions such as George and Maurice, how the deceased's action of

\footnotetext{
${ }^{76}$ [2011] ZAGPJHC 109 (South Gauteng High Court, Johannesburg (now forming part of the Gauteng Division of the High Court of South Africa (HCSA-G))).

${ }^{77}$ ibid [11].

78 ibid.

${ }^{79}$ ibid [2].

${ }^{80}$ ibid [19].

${ }^{81}$ ibid [15].

${ }^{82}$ By operation of the Intestate Succession Act 81 of 1987 (SA), s 1(1)(c)(i).

${ }^{83}$ Mabika (n 76) [15].

${ }^{84}$ ibid [11].

${ }^{85}$ ibid [15].
} 
completing an application form containing instructions for the preparation of a will exhibited the requisite animus testandi. ${ }^{86}$

It is, moreover, highly questionable for a South African judge to invoke, as Moshidi $\mathrm{J} \mathrm{did}{ }^{87}$ concepts of 'justice' and 'fairness' in the abstract to resolve a testamentary condonation application. This is because South African law does not permit the judicial invocation of (un)reasonableness or (un)fairness as freestanding norms in the resolution of legal disputes as to do so is to offend the principle of legality and, accordingly, the rule of law. ${ }^{88}$ Mabika is therefore open to criticism not only on the ground that Moshidi J paid scant regard to section 2(3)'s testamentary intentions requirement, but also that his Honour relied unjustifiably on considerations neither relevant nor pertinent to testamentary rescue. ${ }^{89}$ The outcome in Mabika should therefore have corresponded with those in George and Maurice, and is thus atypical of judicial engagement with will drafting instructions in the context of testamentary rescue. ${ }^{90}$

\section{Other documents}

Courts in Manitoba, British Columbia and South Africa have had to adjudicate on the testamentary rescue of documents that, in their appearance, format and/or general purport, resembled wills to varying degrees. These decisions have yielded diverse outcomes and a quick survey of some of the principal cases on point is instructive.

Decisions dealing with the rescue of formally irregular will templates are arguably the most straightforward of these cases. For example, courts in the two Canadian jurisdictions are generally amenable to rescuing 'fill in the blanks' will templates because testators normally complete these templates with the requisite animus testandi. ${ }^{91}$ At the time of writing, no reported South African judgment exists in which a will template was condoned. Courts in all three jurisdictions have, however, refused to rescue will templates when, in a particular case, the evidence adduced was insufficient to meet the (threshold) authenticity requirement insofar as the evidence did not show on a balance of probabilities that the deceased in fact filled in the template in question or that he or she did so freely and voluntarily. ${ }^{92}$

\footnotetext{
${ }^{86}$ See Michael Cameron Wood-Bodley, 'Can Section 2(3) of the Wills Act 7 of 1953 Properly Be Applied to a Mere Instruction to Draft a Will? Mabika v Mabika' (2013) 130(2) The South African Law Journal 244 for criticism of this decision.

${ }^{87}$ Mabika (n 76) [15].

${ }^{88}$ Potgieter v Potgieter [2011] ZASCA 181 [31], [34]-[36].

${ }^{89}$ See further A van der Linde, 'Longfellow v BOE Trust Ltd NO (13591/2008) [2010] ZAWCHC 117; Mabika v Mabika [2011] ZAGPJHC 109; Taylor v Taylor [2011] ZAECPCHC 48: Requirements in Terms of Section 2(3) of the Wills Act 7 of 1953: Some Comments on Judgments in Recent Case Law' (2012) 45 De Jure 412, 421-22.

${ }^{90} \mathrm{Du}$ Toit (n 13) 73-74.

${ }^{91}$ See, eg, the Manitoban decisions in Prefontaine v Arbuthnott 2001 MBQB 45, McNeil (n 34) and the British Columbian decision in Yaremkewich Estate (Re) 2015 BCSC 1124.

${ }^{92}$ See, eg, Belser v Fleury (1999) 139 Man R (2d) 149 (MBQB); Poulk Estate 2018 BCSC 1321; Longfellow v BOE Trust Ltd [2010] ZAWCHC 117 (Western Cape High Court, Cape Town (now forming part of HCSA-WC)).
} 
The same courts have furthermore rescued formally irregular handwritten notes and letters of various kinds that expressed testamentary intentions. For example, in Estate Beck (Re), ${ }^{93}$ the Supreme Court of British Columbia cured a portion of a letter, written and signed by the deceased but not witnessed, as a codicil to the deceased's existing will. ${ }^{94}$ Similarly, in Smith $v$ Parsons, ${ }^{95}$ the Supreme Court of Appeal of South Africa condoned a handwritten suicide note, signed and dated by the deceased but not witnessed, as an amendment to the deceased's existing will. ${ }^{96}$ The courts in these cases were satisfied that the documents at issue indeed expressed the relevant deceased's testamentary intentions. Moreover, South African courts have rescued documents that existed only in electronic format at the time of the relevant deceased's passing but were subsequently printed and submitted to the courts as paper documents in condonation applications - see, for example, Macdonald $v$ The Master $^{97}$ (where a secure computer file containing the deceased's unsigned will was accessed and printed in the aftermath of his suicide ${ }^{98}$ ) and Van der Merwe (where an email containing the deceased's unsigned will was printed after his death ${ }^{99}$ ). As is the case with the abovementioned handwritten (albeit signed) notes and letters, the courts in these instances were nonetheless satisfied that the unsigned electronic documents, and hence also the printed versions thereof, indeed embodied the relevant deceased's testamentary intentions.

South African courts have, however, refused to condone documents - even documents drafted in a deceased's handwriting and signed by him or her - if not convinced on the balance of probabilities that the document(s) at issue contained the deceased's testamentary intentions. For example, in Taylor $v$ Taylor, ${ }^{100}$ a so-called 'wish list' regarding dealings with the deceased's fixed property, personal effects and the residue of his estate after his death was not condoned, despite the fact that the deceased drafted, signed and dated the document. ${ }^{101}$ Similarly, in Van Straaten $v$ Ottman, ${ }^{102}$ a so-called 'manuscript letter' outlining the deceased's future intentions with regard to the distribution of certain of her assets was not condoned, despite the fact

\footnotetext{
${ }^{93}$ Beck (n 27).

${ }^{94}$ ibid [9]-[11], [24].

${ }^{95}[2010]$ ZASCA 39.

${ }^{96}$ ibid [13]-[14], [23]-[24]. See also Dikgale v Master of the High Court, Polokwane [2013] ZAGPPHC 85 (North Gauteng High Court, Pretoria (now forming part of HCSA-G)) [4], [24], [28] (where Teffo J condoned handwritten extracts from the deceased's diary, signed by the deceased but not witnessed, as the deceased's last will).

${ }^{97} 2002$ (5) SA 64 (0) (Orange Free State Provincial Division of the High Court (now forming part of the Free State Division of the High Court of South Africa (HCSA-FS))).

${ }^{98}$ ibid $67 \mathrm{H}-68 \mathrm{I}, 72 \mathrm{~B}-73 \mathrm{C}$.

${ }^{99}$ Van der Merwe (n 47) [3], [5], [18]-[19].

${ }^{100}$ [2011] ZAECPEHC 48 (Eastern Cape High Court, Port Elizabeth (now forming part of the Eastern Cape Division of the High Court of South Africa (HCSA-EC))).

${ }^{101}$ ibid [9]-[10], [22].

${ }^{102}$ [2015] ZAKZPHC 17 (HCSA-KZN).
} 
that the deceased drafted and dated the letter personally and stated her full name, residential address and date of birth on the document. ${ }^{103}$

\section{Evaluation}

In this section of the article, two issues pertinent to testamentary rescue emanating from the foregoing analysis on the application of the rescue provisions in the three jurisdictions under discussion - are evaluated, namely:

- the 'document issue': how does each of the rescue provisions engage with digital documents for the purpose of testamentary rescue and what improvements, if any, can be proposed in this regard?; and

- the 'testamentary intentions issue': how are a deceased's testamentary intentions in respect of a particular document established and which legal mechanisms aid courts when they adjudicate on this issue?

\section{The document issue}

The British Columbian statute renders any 'record, document or writing or marking on a will or document ${ }^{104}$ open to testamentary rescue and contains an extensive definition of a 'record' ${ }^{\prime 105}$ for that purpose. A plain reading of this definition suggests that data captured in a non-paper format falls within the ambit of the court's testamentary rescue power. This broadened scope is similarly reflected in testamentary rescue provisions in other Commonwealth jurisdictions, ${ }^{106}$ which is unsurprising (particularly in respect of those provisions enacted after the turn of the twenty-first century), given the obvious need to embrace the modern digital age by bringing data captured in formats other than on paper into the testamentary rescue fold. This is because the modern tendency is to move to a digital, paperless society; so much so that even lay persons today interact to ever greater degrees with documents including legal documents such as wills - in a digital manner. ${ }^{107}$

\footnotetext{
${ }^{103}$ ibid [4], [39]-[41].

${ }^{104}$ WESA 2009, s 58(2).

${ }^{105}$ ibid, s 58(1).

${ }^{106}$ See, eg, in respect of Australia's Northern Territory, the Wills Act 2000 (WA 2000), which commenced on 1 March 2001. WA 2000, s 10 provides for when the Supreme Court of the Northern Territory may, in respect of a particular document or part thereof, 'dispense with requirements for execution of wills'. In this connection, WA 2000, s 10(1) defines 'document' as 'a record of information' which, in turn, includes '(a) anything on which there is writing; (b) anything on which there are marks, figures, symbols or perforations having a meaning for persons qualified to interpret them; $(c)$ anything from which sounds, images or writings can be reproduced with or without the aid of another thing or device; (d) and a map, plan, drawing or photograph.' This statutory description of 'a record of information' clearly encompasses more than documents of the traditional paper variety.

${ }^{107}$ See, eg, Re Yu [2013] QSC 322 (Supreme Court of Queensland) [1], [4]-[5], [9]. In that case, the deceased created 'a series of documents on his iPhone' shortly before he died, one of which 'was expressed to be his last Will'. An application was made for this 'electronic document' to be declared the deceased's will
} 
It is, arguably, equally unsurprising that 'older' rescue provisions, such as those contained in the Manitoban and South African wills statutes, do not contain definitions of 'document' or 'record' such as the one found in the British Columbian statute. These 'older' provisions were, of course, enacted at times when the digitalisation of documents and records was not as pertinent and prevalent as is currently the case. Nevertheless, South African courts have had to adjudicate on the rescue of documents that existed only in electronic format at the times when the persons who prepared them passed away. As evidenced in the case studies above, however, these documents were readily converted to paper documents by, for example, printing out a computer file ${ }^{108}$ or an e-mail. ${ }^{109}$ Accordingly, South African scholars have posed the question whether the South African rescue provision can, as it currently reads, occasion a similar result in respect of, for example, electronic documents or records that cannot, for whatever reason, be converted to hard copy format. ${ }^{110}$ Some have proffered an affirmative answer to this question, but at the same time conceding that this is a grey area of the South African law of wills and that a positive outcome is not guaranteed in the event that an electronic document or record is brought before a court for condonation. ${ }^{111}$ It is submitted that these questions and uncertainties justify a reappraisal of 'older' rescue provisions with a view to including a more contemporary approach to document creation and data capture in the relevant statutes. It stands to reason that the British Columbian wills statute provides invaluable guidance and direction to this end.

\section{The testamentary intentions issue}

Determining whether a document embodies a deceased's testamentary intentions - a requirement common to testamentary rescue in all three of the jurisdictions under discussion - is (at least at times) particularly troublesome. Adjudication on this matter invariably turns on a consideration of: the document itself; the circumstances surrounding the document's creation; and the (would-be) testator. Sometimes a court, having considered these

pursuant to the applicable testamentary rescue provision: Succession Act 1981 (QId) (SA 1981), s 18. SA 1981, s 5 defines 'document' for the purposes of SA 1981, s 18 as the definition contained in Schedule 1 of the Acts Interpretation Act 1954 (QId), which definition largely mirrors WA 2000, s 10(1) (as to which, see $n$ 106). Lyons J was thus satisfied that the record on the deceased's iPhone was indeed a document within the meaning of SA 1981, s 18 and his Honour granted an order for it to be admitted to probate.

${ }^{108}$ See text to $\mathrm{n} 98$.

${ }^{109}$ See text to $\mathrm{n} 99$.

${ }^{110}$ See, eg, Linda Schoeman-Malan and others, 'Section 2(3) of the Wills Act 7 of 1953: A Retrospective and Critical Appraisal of Some Unresolved Issues' [2014] Acta Juridica 78, 87.

${ }^{111}$ See, eg, Michael Cameron Wood-Bodley, 'Macdonald v The Master: Computer Files and the 'Rescue' Provision of the Wills Act' (2004) 121 The South African Law Journal 34 and Michael Cameron Wood-Bodley, 'Wills, Data Messages, and the Electronic Communications and Transactions Act' (2004) 121 The South African Law Journal 526. 
factors, readily and correctly finds that the testamentary intentions requirement has been met. For example, in Litke Estate (Re), ${ }^{112}$ the Supreme Court of British Columbia had no difficulty in holding that a 'will-like document' (namely, a single piece of paper with writing on both sides signed and dated by the deceased ${ }^{113}$ ) contained the deceased's testamentary intentions because the deceased, although of advanced age at the time, produced the document in 'firm, legible, well formed, and attractive' handwriting; ${ }^{114}$ entitled the document 'My Will and Testament' and 'took care to date it'; made specific bequests to her daughters and grandson; ${ }^{116}$ appointed the executors of her estate; ${ }^{117}$ and made provision for gravestones for both her and her deceased husband. ${ }^{118}$ In light of these facts, Brown J had no hesitation in finding that the document represented the deceased's testamentary intentions and that the document, although not witnessed so as to satisfy the formal requirements for a valid will, ${ }^{119}$ had to be fully effective as the deceased's will. $^{120}$

Adjudication on the testamentary intentions issue is, however, often not as straightforward as in Litke. For example, in Lane Estate, ${ }^{121}$ the Supreme Court of British Columbia had to determine whether a series of handwritten notes represented the deceased's intention to alter her existing will. Pearlman J identified certain factors that might support a finding to that effect, namely: that the deceased used formal, will-like language in several of the notes; signed some of the notes; informed the petitioner that she wanted him to have her house after she died and that she had left a note to that effect; and six of the notes contemplated a distribution of the deceased's residuary estate in favour of the petitioner only. ${ }^{122}$ At the same time, Pearlman J also acknowledged that certain factors weighed against a finding that one or more of the notes represented the deceased's testamentary intentions, namely: the notes were written on the back of a receipt, grocery list, calendar, or other scrap paper (which suggested a measure of impermanence and informality); none of the notes were witnessed (and thus all failed to satisfy the formal requirements for a valid will); none of the notes expressly revoked the deceased's existing will; none of the notes bore a title (let alone a title that suggested they were contemplated as testamentary instruments); the time of writing of certain of the notes suggested they

\footnotetext{
${ }^{112} 2017$ BCSC 1079.

${ }^{113}$ ibid [9].

${ }^{114}$ ibid [45].

${ }^{115}$ ibid [47].

116ibid [50]-[51].

${ }^{117}$ ibid [46].

${ }^{118}$ ibid [49].

${ }^{119}$ ibid [43].

${ }^{120}$ ibid [53].

${ }^{121} 2015$ BCSC 2162.

${ }^{122}$ ibid [44].
} 
may not represent an expression of the deceased's fixed and final testamentary intentions; and some of the notes were in the form of personal communications addressed to the petitioner rather than formal testamentary documents. ${ }^{123}$ Pearlman J, having weighed all of these factors, concluded that the notes, whether considered individually or collectively, did not, on a balance of probabilities, represent a deliberate and final expression of the deceased's testamentary intentions and that the notes could thus not be rescued. ${ }^{124}$

Lane shows that the outcome of a testamentary rescue case often turns on whether or not the applicant can, on the evidence adduced, meet the quantum of proof regarding the presence of the requisite intention on the deceased's part. The exercise of a court's power of testamentary rescue is, after all, 'inevitably and intensely fact-sensitive.' ${ }^{125}$ Where, in a case such as Lane, the facts at hand are not summarily unequivocal, the applicant (if his or her testamentary rescue application is to be successful) must show that, despite the presence of possible countervailing facts, the preponderance of the evidence supports the conclusion that the document at issue indeed represents the deceased's testamentary intentions. The petitioner in Lane failed in this regard insofar as evidence regarding key aspects of the deceased's testamentary intentions was lacking. This dearth of evidence and the petitioner's consequent inability to meet the quantum of proof ultimately determined the outcome in Lane. ${ }^{126}$

Lane is instructive also for another reason. Pearlman J was at pains to distinguish Beck from the matter before him. ${ }^{127}$ In Beck, the deceased left instructions for the letter in question to be read out by her lawyer and she left a copy of the letter with her executor. The court in Beck attached significant probative weight to these actions performed prior to the deceased's death. ${ }^{128}$ Conversely, in Lane, the deceased neither showed nor provided copies of the notes in question to anyone else before she died. ${ }^{129}$ These factual differences between the two cases permitted Pearlman J to decide Lane without being bound by the doctrine of precedent. Of course, had the facts in Lane resembled that of Beck more closely, the outcome in the former case may well have been different because Pearlman J would have had to follow the precedent set in the latter case. Moreover, a petitioner in such a factually analogous case could have invoked the earlier precedent-setting decision to secure a favourable outcome.

\footnotetext{
${ }^{123}$ ibid [46].

124 ibid [48]-[49].

${ }^{125}$ Young (n 31) [34].

${ }^{126}$ Lane (n 121) [48]-[49].

${ }^{127}$ ibid [39]-[41], [46(d)]

${ }^{128}$ Beck (n 27) [18]-[19].

${ }^{129}$ Lane (n 121) [46(d)].
} 
South African case law shows, however, that precedent is not necessarily an accurate predictor of the outcome of a testamentary rescue case, in particular insofar as adjudication on the testamentary intentions issue is concerned - for example, the contrasting outcomes in Van der Merwe and Dryden v Harrison. ${ }^{130}$

In Van der Merwe, the court noted (amongst other things) that: ${ }^{131}$

- the email in question (which in its appearance resembled a will) was entitled 'TESTAMENT' in large type print;

- in the email, the deceased nominated the appellant as the sole beneficiary of his estate (apparently pursuant to an agreement between the deceased and the appellant that each would nominate the other as sole beneficiary of their respective estates);

- the appellant was the only beneficiary of the deceased's pension fund;

- the appellant was the deceased's long-time friend and confidante; and

- the appellant, having received the emailed will from the deceased, indeed reciprocated by executing a will in which the deceased was nominated as his sole beneficiary.

These facts led to 'the inexorable conclusion that the document was intended by the deceased to be his will. ${ }^{132}$

In the subsequent decision of Dryden, the deceased sent the following email to the applicant (his fiancée) around nine months prior to his death with the subject line 'Final will':

$\mathrm{Hi}$,

This serves as my final will and testament.

If I die, all my assets and investments go to Natasha Dryden. If Natasha's death precedes mine, the entire estate goes in equal portions to my brother and sister or their children if their deaths proceed (sic) me.

My life policies must all $\mathrm{g}$ (sic) to Natasha. ${ }^{133}$

The applicant's petition to have this email condoned as the deceased's will was, despite similarities with the factual matrix at hand in Van der Merwe, unsuccessful. Nuku J was unconvinced by the facts that the email:

- explicitly identified (as did the email in Van der Merwe) its contents as being the deceased's last will and testament;

- designated (as was the case in Van der Merwe) the applicant as the deceased's only named beneficiary; and

\footnotetext{
${ }^{130}$ Case No. 11912/17 (HCSA-WC, 20 May 2019).

${ }^{131}$ Van der Merwe (n 47) [3], [5], [18].

${ }^{132}$ ibid [18].

${ }^{133}$ Dryden (n 130) [6].
} 
- awarded the deceased's life policies to the applicant as sole beneficiary (as happened in Van der Merwe in respect of the deceased's pension fund proceeds).

His Honour instead regarded the email as nothing more than an assurance to the applicant that she would eventually benefit from the deceased's estate. ${ }^{134}$ In fact, Nuku J distinguished Van der Merwe from the matter before him on the ground that the deceased prepared the document at issue in Van der Merwe in such a way that it could readily be executed (the email contained spaces for the testator's and witnesses' signatures), whereas the document in Dryden 'was not prepared as a document intended to be signed by the deceased and the witness. $^{135}$ Respectfully, this is a tenuous deduction based by and large on the appearance or format of the document at hand. As discussed above, earlier South African judgments on point have shown that the appearance or format of the document at issue is not determinative to an assessment of the deceased's testamentary intentions. ${ }^{136}$ Nuku J should thus have acknowledged that the substantive factual similarities between Van der Merwe and Dryden outweigh the lesser factual differences between the two cases to such an extent that the same outcome ought have ensued. The question regarding the deceased's testamentary intentions before Nuku J in Dryden should therefore have been answered with greater deference to the precedent set by a higher court in Van der Merwe.

The foregoing evaluation shows that the testamentary intentions issue poses challenges to courts adjudicating on testamentary rescue cases in Manitoba, British Columbia and South Africa. It is difficult, if not impossible, to distil 'hard-and-fast' rules regarding such adjudication from the three jurisdictions' rescue cases. This is undoubtedly because a rescue case, by its very nature, deals with a fundamentally subjective question, namely the state of mind of a person who has passed away. Answering this question involves a fact-sensitive and contextually-variable judicial inquiry. Objective legal mechanisms in other words, mechanisms that function extraneously to the subjectivities of a particular case - are essential aids to courts in their adjudication in rescue cases. The foregoing evaluation of the testamentary intentions issue shows that the quantum of proof and the doctrine of precedent, although controversial in some decisions, are the principal objective legal mechanisms determinative to the outcomes in rescue cases.

\section{Conclusion}

This article commenced with an explanation regarding the role of testamentary formalism and the functional importance of adherence to testamentary

\footnotetext{
${ }^{134}$ ibid [17].

135 ibid [18].

${ }^{136}$ See text to $n$ 95-96.
} 
execution formalities. It also highlighted the tension between testamentary formalism and one of the cornerstones of the law of wills, namely effectuating testators' dispositive plans. The testamentary rescue provisions of the Manitoban, British Columbian and South African wills statutes seek to diffuse this tension by allowing courts to 'cure', 'dispense with', or 'condone' (as applicable) non-compliance with testamentary execution formalities in formally irregular documents that embody the testamentary intentions of deceased persons. In this regard, the British Columbian rescue provision's engagement with document creation and data capture in a digital age suggests that its Manitoban and South African counterparts, both of earlier origin than the British Columbian provision, require modernisation to bring greater legal certainty regarding which documents can be subject to rescue applications.

Courts in all three jurisdictions readily rescue documents that are proven to be authentic embodiments of deceased persons' testamentary intentions. This combination of a threshold authenticity requirement and a core testamentary intentions requirement ensures that a rescued document, although formally irregular, nevertheless conforms functionally to a duly-executed will. The analysis of jurisprudence in this article therefore shows that courts generally issue rescue orders only when they are satisfied that the documents at issue, despite not complying (fully) with statutory execution prescripts, are nevertheless aligned to, in particular, the evidentiary and cautionary functions performed by testamentary execution formalities. ${ }^{137}$ Courts in all three jurisdictions under discussion will thus issue rescue orders only if they are convinced, on a preponderance of the evidence adduced, that a particular document contains the deceased's volition regarding the distribution of his or her property after death and that the deceased indeed comprehended the significance of making the document that purports to be a will.

Testamentary rescue cases by their very nature - and notwithstanding the objective legal mechanisms such as the quantum of proof and the doctrine of precedent that aid courts in their adjudication of these cases - inevitably yield some dissonant and criticisable judgments. De Waal and Schoeman-Malan (in their assessment of the South African rescue provision) nevertheless conclude that the legislature's aim - namely, the creation of a legal mechanism for effectuating deceased persons' testamentary intentions - has by and large been achieved. ${ }^{138}$ This article shows that the same holds true for the Manitoban and British Columbian rescue provisions.

\footnotetext{
${ }^{137}$ George (n 25) [22].

${ }^{138}$ De Waal and Schoeman-Malan (n 20) 79.
} 


\section{Acknowledgments}

Some of the research for this article was conducted during a sabbatical period spent at the Paul M Hebert Law Center, Louisiana State University with the financial assistance of the South African National Research Foundation (NRF).

\section{Notes on contributor}

The author is a Senior Professor and the Head of the Private Law Department at the University of Western Cape, South Africa. 